\title{
Merunut Potensi Kopi Arabika Sebagai Pengusung Utama Komoditas Ekpor Provinsi Bali
}

\author{
I Dewa Gede Raka Sarjana1), Dwi Putra Darmawan²), Ni Wayan Sri Astiti³) \\ Program Studi Magister Agribisnis, Program Pascasarjana, Universitas Udayana, \\ E-mail Correspondent: idewegederakasarjana@yahoo.com \\ 1) Program Studi Magister Agribisnis, Program Pascasarjana, Universitas Udayana \\ 2) Program Studi Magister Agribisnis, Program Pascasarjana, Universitas Udayana \\ 3) Program Studi Magister Agribisnis, Program Pascasarjana, Universitas Udayana
}

\section{ABSTRACT \\ Treating Arabica Coffee Potentials As A Main Sector Of The Export Commodity Bali Province}

The last 5 years of Balinese economic growth has been stagnant (on average 5.5\%), while it is better than the national economic growth (5.02\%). Given these facts, Balinese economic development needs to be directed to the source of new economic growth to create a progressive, inclusive and equitable acceleration of economic growth towards the equity of the wider society. In line with this intention, this study aims to map the potential industry which then becomes the candidate for new economic growth.

This study was using a descriptive research design, in which the researchers interacted intensely with key informants and various sources of reference, related to the field under study. Methodologically these assessment activities may include careful study (observation, field survey and documentary studies of the potential of arabica coffee that can be identified as future business opportunities.

Coffee plants (Coffee Sp.) in addition to having a strategic value in the economic development of society, especially in rural areas. Its role is increasingly important considering the coffee garden place the highest position in terms of coffee ownership in the province of Bali. The development of the last 10 years, increased the area of planting area by $3.04 \%$, production by $27 \%$ per year, and the productivity (ose) an average of $1000 \mathrm{~kg} / \mathrm{ha} /$ year. Until now Bali province ranks the top 10 coffee producers in Indonesia with planting area of 23,614 ha for Robusta and 9,448 ha for Arabica. The contribution of Arabica coffee to Bali's coffee export commodity recently shows a significant increase in both quantity and quality. In terms of overall potential in Bali (22,974 ha), most (20,840 ha) are located in 4 arabica coffee producer regencies, including: Bangli (12,589 ha); Karangasem (3,419 ha); Buleleng (3,400 ha) and Badung 1,413 ha. However, in its development until 2014 the potential area can only be realized as a community plantation of 9,780 ha covering 3 regencies such as: Bangli, Buleleng and Badung, so there is still a potential remaining $46.4 \%$ of Bali's potential as a whole. In terms of production quality, the three production centers have excellent taste quality (the test results are rated Very Good-Excelent by the score 7-8), so it is now known as Balinese coffee and classified having Geographical Indication with lemon flavor.

Keywords: Economic growth; the potential of Arabica coffee, and; Balinese coffee 


\section{Pendahuluan}

Pertumbuhan ekonomi global pada triwulan awal tahun 2017 ini mulai membaik, diduga tidak terlepas dari perbaikan kinerja ekonomi negara maju seperti AS dan negara-negara di eropa. Sementara itu kontribusi dari negara-negara berkembang dipastikan sangat beragam. Namun fenomena keberhasilan tersebut kedepannya tetap mengandung sejumlah resiko yang mengkhawatirkan dan membayangi kondusifitas ekonomi global yang belum solid. Tantangan yang terjadi bisa dalam wujud resiko geopolitik terkait isu terorisme global, dan konsistensi kebijakan perdagangan negara-negara maju.

Dari sudut pandang Indonesia, perbaikan pertumbuhan ekonomi Indonesia masih selaras dengan pertumbuhan ekonomi dunia saat kini. Tumbuh membaik yaitu sebesar 5.02\% dibandingkan tahun sebelumnya hanya mencapai 4,95\% (Laporan BI tahun 2016). Terkait dengan pertumbuhan ekonomi nasional tersebut, ekonomi Bali tumbuh lebih baik yaitu sebesar $5,47 \%$ pertahun, hal ini disinyalir karena kontributor sektor pariwisata. Meskipun demikian besarnya ketergantungan ekonomi Bali terhadap pariwisata sebagai sektor unggulan daerah akan mengandung resiko besar dikemudian hari, tatkala terjadi gangguan terhadap perekonomian dunia, termasuk isu terorisme yang semakin kuat. Kondisi seperti tersebut meniscayakan setiap wilayah otonomi daerah tanpa kecuali Provinsi Bali untuk bebas dari ketergantungan, perlu diarahkan untuk mencari sumber pertumbuhan ekonomi yang berbasis pada potensi sumberdaya lokal. Selain itu akselerasi pertumbuhan ekonomi diperlukan untuk mendorong pencapaian target pertumbuhan sebesar 7 \% sesuai Nawacita pemerintah Republik Indonesia saat ini. Hal ini tentunya menuntut upaya dalam perencanaan yang konfrehensip.

Perencanaan strategis pada hakekatnya mencari kesesuaian antara kondisi internal dan eksternal. Hal ini dimaknai sebagai upaya untuk mempertahankan dan atau mengembangkan potensi ekonomi komoditas potensial, dan pangsa pasar produk serta mencari peluang bisnis yang baru. Terkait dengan pencapaian tujuan tersebut, strategi pembangunan ekonomi daerah yang progresif, inklusif dan berelisiansi serta berkelanjutan dipandang perlu pemetaan potensi sumberdaya yang dapat digunakan sebagai sumber pertumbuhan ekonomi yang baru. Konskuensi logis dari sebuah perencanaan adalah menuntut sejumlah informasi yang terkait dengan potensi komoditas potensial sebagai pengusung ekspor dari suatu wilayah atau daerah. Oleh karena itu pengkajian ini dimaksudkan sebagai langkah awal yang penting dalam pengembangan kawasan perkebunan khususnya sebagai pengurai simpul kritis pembangunan pertanian guna menyokong pembangunan perekonomian Bali dan Nasional.

Adapun tujuan dari pengkajian ini adalah :

1. Menganalisis profil bisnis kopi Arabika sebagai komponen strategis komoditas ekspor Provinsi Bali dari sisi potensi produksi

2. Menganalisis potensi ekonomi yang terkait dengan keunggulan komparatif dan kompetitif komoditas kopi Arabika di Provinsi Bali

3. Menganalisis kondisi eksisting Perkembangan Kopi Arabika di Provinsi Bali

\section{Metodologi Pengkajian}

Pengkajian ini dilaksanakan dengan rancangan penelitian deskriptip, dimana peneliti berinteraksi secara intens dengan informan kunci dan berbagai sumber refrensi terkait bidang yang diteliti. Secara metodologis kegiatan pengkajian ini dapat meliputi pengamatan cermat (observasi, dan survey lapangan maupun studi dokumentasi terhadap potensi kopi arabika yang 
dapat diidentifikasi sebagai peluang bisnis kedepan. Sebagai responden kunci : Kepala Dinas Perkebunan Provinsi Bali, Kabid produksi Dinas Perkebunan Prov. Bali; Unit Manajemen Lapangan dan Kelian Subak Abian. Sedangkan sebagai responden adalah Ketua Kelompok Tani dan petani. Instrumen penelitian berupa pedoman wawancara dan kuisioner.

\section{Hasil Kajian Dan Pembahasan}

\section{Analisis Profil Bisnis Kopi Arabika dari Sisi Potensi Produksi}

Persepektif sejarah perkopian Bali, telah berlangsung sejak lama, sampai saat ini di beberapa kabupaten di Provinsi Bali berkembang kawasan kopi Arabika hingga 13.000 Ha. Eksistensi Proyek Rehabilitasi dan Pengembangan Tanaman Ekspor (PRPTE) tahun 1979 membangkitkan kembali kejayaan kopi di Provinsi Bali ini melalui pemberian bantuan bibit unggul dengan berbagai varietas seperti : lini S 795; Usda klon 762 dan Kartika dan kopi Kopyol. Dengan pengawalan teknologi budidaya beserta unit pengolahan hasil (UPH) dengan sistem olah basah, menyebabkan produk ekpor Bali unggul dalam citarasa dan disenangi para bayer luar negeri dengan harga yang sangat kompetitif. Meski masih rendah dalam kuantitas (1000 kg Ose/Ha/tahun) dibandingkan dengan kopi robusta yang mencapai produktivitas ratarata 700-800 kg /Ha. Dalam perjalanan waktu kopi Arabika di kabupaten Bangli mulai berkembang ke beberapa daerah Kabupaten lainnya di Provinsi Bali yang meliputi : Buleleng, Badung bahkan sampai Karangasem dan kabupaten lainnya. Kini berdasarkan data statistik Dinas Perkebunan Provinsi Bali Tahun 2015 di wilayah ini perkebunan kopi rakyat mencapai 23. $000 \mathrm{Ha}$ jenis Robusta dan 9.448 ha jenis Arabika serta teridentifikasi potensi luas peruntukan (kesesuaian agroklimat) masing-masing $31.017 \mathrm{Ha}$ dan 22.974 Ha. Hal ini menunjukkan sebagai besaran potensi komoditas kopi Arabika dan peluang bisnis kedepan. Namun secara relatif kerap terjadi pasang surut luas produksi, yang disebabkan oleh dinamika alih fungsi lahan akibat fluktuasi harga kopi dunia.

Dinamika luas produksi kopi di Provinsi Bali (sentra Arabika) baik karena alih fungsi lahan maupun harga ekpor menjadi tantangan tersendiri bagi pemerintah. Komitmen pemerintah yang kuat mampu memotivasi petani kopi kembali melalui upaya rehabilitas, intensifikasi dan peremajaan tanaman disertai penataan terorganisir secara kelembagaan dalam bentuk Subak Abian ( 290 Subak Abian) dan disertai penguatan fasilitas pengolahan di 46 UPH diseluruh Bali. 
Tabel 1.

Estimasi Potensi Areal Komoditas dan Luas Areal Tanam Kopi di Provinsi Bali (2015)

\begin{tabular}{|l|l|l|l|c|}
\hline \multicolumn{1}{|l|}{ Jenis } & Kabupaten & Potensi (Ha) & Area Tanam (Ha) & Sisa Potensi (\%) \\
\hline 1. & Bobusta & 12.250 & 10.782 & $(11,83)$ \\
\hline & Tabanan & 10.450 & 9.555 & $(8)$ \\
\hline & Karangasem & 3.263 & 900 & $(72)$ \\
\hline & Bangli & 1.184 & 355 & $(7)$ \\
\hline Arabika & Bangli & 12.589 & 4.303 & $(65,7)$ \\
\hline & Karangasem & 3.419 & 828 & $(75,7)$ \\
\hline & Buleleng & 3.419 & 2.234 & $(24,3)$ \\
\hline Jumlah & Badung & 1.413 & 1.371 & $(20)$ \\
\hline Bali & & $\mathbf{2 0 . 8 4 0}$ & $\mathbf{8 . 7 4 1}$ & \\
\hline
\end{tabular}

Sumber : Statistik Dinas Perkebunan Provinsi Bali (2015)

Dapat disebutkan bahwa potensi areal sesuai peruntukan kopi robusta (ketinggian tempat 500-700 m dpl) mencapai $31.017 \mathrm{Ha}$ yang meliputi beberapa kabupaten seperti : Tabanan, dan Buleleng bagian bawah. Namun sesuai data Dinas Perkebunan Provinsi Bali sampai dengan tahun 2015 baru dikembangkan sebanyak 23. 614 ha diseluruh Bali (79,1\%). Berbeda dengan potensi wilayah peruntukan kopi Arabika (ketinggian diatas $900 \mathrm{~m}$ dpl.) adalah sebesar 22.974 ha dan baru bisa dikembangkan 9.448 ha (sekitar $41.9 \%$ ). Hal ini berarti peluang pengembangan kopi arabika masih terbuka lebar, selain lebih besar, pula lebih menarik bagi petani kopi khususnya di sentra-sentra kopi arabika. Indikasi kearah hal tersebut, perkembangan areal tanam kopi arabika sepuluh tahun belakangan dapat dilihat seperti pada Tabel 2.

Tabel 2.

Perkembangan Luas Penanaman Kopi Arabika di Provinsi Bali Tahun 2010- 2015

\begin{tabular}{|l|l|l|l|l|l|}
\hline Kabupaten & $\mathbf{2 0 1 0}$ & $\mathbf{2 0 1 1}$ & $\mathbf{2 0 1 2}$ & $\mathbf{2 0 1 3}$ & $\mathbf{2 0 1 4}$ \\
\hline Bangli & 4.303 & 4.737 & 5.606 & 5.600 & 5.600 \\
\hline Buleleng & 2.239 & 2.687 & 2.687 & 2.714 & 2.767 \\
\hline Badung & 1.371 & 1.371 & 1.413 & 1.413 & 1.413 \\
\hline Jumlah & $\mathbf{7 . 9 0 3}$ & $\mathbf{8 . 7 9 5}$ & $\mathbf{9 . 7 0 6}$ & $\mathbf{9 . 7 2 7}$ & $\mathbf{9 . 7 8 0}$ \\
\hline Bali & $\mathbf{9 . 4 6 3}$ & $\mathbf{1 0 . 4 9 1}$ & $\mathbf{1 1 . 9 3 9}$ & $\mathbf{1 1 . 1 5 5}$ & $\mathbf{1 2 . 8 8 1}$ \\
\hline
\end{tabular}

Sumber : Statistik Dinas Perkebunan Provinsi Bali (2015)

Potensi pengembangan sub-sektor perkebunan (kopi Arabika) masih terbuka, oleh karena itu konsep pengembangan diarahkan untuk mewujudkan perkebunan rakyat yang produktif, efisien dan berdaya saing. Langkah besarnya adalah mewujudkan kualitas kopi premium secara berkelanjutan ditopang kelembagaan sosio-bisnis yang berorientas pasar lokal hotel berbintang, dan pasar ekpor. Untuk itu butuh upaya pemanfaatan sumberdaya perkebunan secara optimal guna mendukung kehandalan ekonomi pedesaan, ketahanan sosial budaya dan lingkungan hidup. Kebijakan dasar yang perlu dilakukan adalah penguatan sub-sistem hulu, pemberdayaan sub-sistem budidaya dan memperkuat sub-sistem hilir. Penguatan aliansi antar sub-sistem diawali pembentukan organisasi pengelola produksi (setiap desa dibangun Subak Abian) yang difasilitasi sarana pengolahan hasil (UPH). Untuk pengembangan pasar (sub-sistem hilir) hasil pengolahan di tingkat UPH ditampung melalui lembaga usaha bersama (koperasi). Sehingga melalui penguatan kelembagaan ini berharap terjadi perubahan manajemen kawasan 
industri kopi di Bali sekaligus meningkatnya income generating petani selain farm; marketing dan pariwisata.

Kondisi exsisting aktivitas pasca panen dan pengolahan saat kini di Kawasan Industri Perkebunan (KIMBUN) terbatas pada pengolahan kopi gelondong baik dalam bentuk kopi greenbean/HS ( estimasi $70 \%$ ) dan kopi beras/Ose (30\%), ditenggarai sebatas untuk kebutuhan pasar ekpor. Bentuk olahan kopi lainnya seperti kopi bubuk hanya dilakukan oleh kelompok tani, sebatas konsumsi sendiri, belum ada upaya kreatif produk premeum dalam wujud kopi spesialty. Namun demikian pertumbuhan usaha pengolahan kopi bubuk secara individu sudah mulai meningkat dari tahun ke tahun. Kondisi perkembangan usaha pengolahan kopi bubuk khususnya kopi robusta di masyarakat lebih berkembang dibandingkan usaha pengolahan kopi arabika. Hal ini tidak terlepas dari kesenjangan harga antar komoditas kopi tersebut, dimana kopi jenis arabika jauh lebih mahal (Rp.50-60 ribu/kg kopi beras), sedangkan harga jenis robusta sebesar Rp. 20-25 ribu/kg). Fenomena ini amatlah strategis sebagai basis untuk menciptakan produk kopi premium dan spesialty Bali coffee secara berkelanjutan dalam memenuhi kebutuhan pasar lokal hotel berbintang yang banyak berkembang di Provinsi Bali.

\section{Analisis Keunggulan Kompetitif Kopi Arabika}

Dari keseluruhan Informan Kunci dan Responden yang diwawancarai diketahui bahwa rata-rata penguasaan tanah pekebun kopi 1,60 ha dengan rentang 0.5-5,5 ha. Dari luas kepemilikan tersebut yang diusahakan sebagai kebun kopi rata-rata 1,2 ha $(60 \%)$. Hal ini menunjukkan besaran peluang pengembangan kopi masih terbuka. Mengingat dari sisi agroklimat cukup sesuai dan minat petani besar serta peluang peningkatan pendapatan petani terbuka lebar. Produktivitas diperkirakan bisa meningkat dari 4,2 ton (gelondong merah) menjadi 5,5 ton per tahun (musim). Berangkat dari data tersebut dengan harga produksi saat ini mencapai Rp.8000/kg dan tingkat produksi 4,2 ton maka estimsi penerimaan pelaku usaha bisa mencapai Rp. 32.000 .000 - Rp. 35.000 .000 per musim. Keadaan ini berbeda signifikan dibandingkan dengan kopi jenis robusta (harga rata-rata berkisar Rp.20.000 - Rp.25.000/kg). Selain dari sisi harga tersebut kopi Arabika asal Bali memiliki keunggulan dari segi geografis (Sertifikat Indikasi Geografis) dengan citarasa lemon. Diperkirakan faktor tinggi tempat (diatas $800 \mathrm{~m} \mathrm{dpl.);}$ jenis penaung dan varietas/klon dan kejaguran tanaman menjadikan kopi arabika asal Bali menjadi terkenal di Manca Negara seperti Jepang, Korea dan Amerika Serikat. Hasil kajian tentang uji citarasa yang dilakukan di Pusat Penelitian Kopi dan Kakao Jember menunjukkan bahwa beberapa sentra produksi kopi Arabika (100\% Kopyol) : Subak Abian Tri Guna Karya Catur; SA Padang Payung Dausa; SA Wanagiri Sukasada; SA Giri Tani Sukasada mempunyai citarasa tergolong Very Good (skor rata-rata 7.25). Sedangkan sentra produksi kopi lainnya yang terdiri dari beberapa jenis klon Arabika, pula memiliki citarasa yang relatif sama. Bahkan ada beberapa sentra produksi seperti : SA. Leket sari Sukasada dan SA. Ulian Murni (50 \% kopyol dan 50\% Lini S 795) mencapai skor 8. Hasil pengujian selengkapnya dapat dilihat seperti pada Tabel 3. 
Tabel 3.

Hasil Pengujian Catarasa Kopi Arabika di Beberapa Sentra Produksi di Bali.

\begin{tabular}{|c|c|c|c|c|c|}
\hline No & Nama Subak Abian & Min-Max & Rata-rata & Katagori & Komposisi varietas \\
\hline \multirow[t]{2}{*}{1} & Tri Guna Karya (catur); Padang & \multirow[t]{2}{*}{$6.75-7.5$} & \multirow[t]{2}{*}{7.25} & \multirow[t]{2}{*}{ Very-good } & \multirow[t]{2}{*}{$100 \%$ kopyol } \\
\hline & $\begin{array}{l}\text { Payung Dausa; Wanagiri } \\
\text { (Sukasada) }\end{array}$ & & & & \\
\hline 2 & $\begin{array}{l}\text { Leket sari (Sukasada); Sukamaju } \\
\text { (Langkan) }\end{array}$ & $7.50-8.00$ & 7.66 & Very-good & $\begin{array}{l}75 \% \text { kopyol } 25 \% \\
\text { jenis Lini S } 795\end{array}$ \\
\hline 3 & $\begin{array}{l}\text { Ulian Murni (kintamani) dan } \\
\text { Padang Payung (Dausa) }\end{array}$ & $7.25-7.50$ & 7.33 & Very good & $\begin{array}{l}50 \% \text { Kopyol dan } \\
50 \% \text { jenis lain }\end{array}$ \\
\hline 4 & Lembu Nandini dan Ulian Murni & $7.25-7.30$ & 7.25 & Very good & $25 \%$ kopyol \\
\hline 5 & Buktiyasa; Padang Payung & $6.00-7.55$ & 7.00 & Very good & $\begin{array}{l}\text { Kopi Berri. Dan } \\
\text { Kopi Ungu }\end{array}$ \\
\hline
\end{tabular}

Berdasarkan informasi tersebut bahwa di Provinsi Bali ada beberapa jenis kopi Arabika yang dikembangkan oleh masyarakat yaitu : varietas/ klon Arabika Lini S 795; Kopi Ungu; Klon Kobra ; Jenis Kopyol (Varietas Unggul Lokal). Keseluruhan varietas /klon tersebut mempunyai citarasa relatif sama yaitu : dengan rentang skor 7.0 - 8.0 dan termasuk dalam kreteria Very good. Berdasarkan analisis sidik ragam ternyata proforsi jenis varietas yang ditanam baik secara monokultur maupun campuran memiliki perbedaan citarasa yang tidak signifikan. Hal ini dapat dimaknai bahwa keragaman jenis kopi arabika yang dikembangkan di Provvinsi Bali belum berdampak terhadap penurunan citarasa Kopi ekspor asal Bali, justru dapat sebagai pendukung mutu dengan klasifikasi Very good (skor rata-rata 7.5).

\section{Analisis Permasalahan}

Dari sisi tantangan masih dijumpai beberapa permasalahan yang utama sebagai berikut:

1. Belum optimalnya upaya pemberdayaan ekonomi masyarakat, Hal ini terindikasi dari lemahnya posisi tawar kopi rakyat baik ditinjau dari sistem produksi dan distribusi kopi olahan di Provinsi Bali. Selain itu industri hilir masih terbatas pada produk-produk olahan untuk konsumsi lokal semata, sehingga tidak mampu sebagai pengungkit aktivitas bisnis di kawasan pertanian.

2. Aliansi kerjasama antar sub-sektor dan atau antar sub-sistem agribisnis maupun antar instansi belum terbangun secara optimal. Ada kegagalan dalam pemahaman tentang orientasi manajemen pengembangan sistem agribisnis. Pendekatan sistem agribisnis kerap dipandang hanya sebatas usaha produktif yang tidak memiliki keterkaitan kedepan atau ke belakang. Butuh komitmen dari berbagai pihak (pelaku agribisnis) dan instansi pemerintah untuk mendukung pencapaian tujuan bersama (pemberdayaan bersama).

Permasalahan tersebut memerlukan penajaman kembali (breakdown) berdasarkan pertimbangan efektifitas manajemen sistem yang dapat dilakukan melalui analisis SWOT. Adapun hasil evaluasi SWOT terhadap kondisi eksisting perkopian di Provinsi Bali dapat diinformasikan sebagai berikut :

1. Kekuatan : meliputi ketersediaan bahan baku kopi yang didukung oleh keunggulan indikasi geografis dan disokong kelembagaan sosial Subak Abian di setiap sentra produksi. Sifat-sifat unggul produk kopi dalam citarasa yang khas (lemon taste) dan potensi pasar kopi spesialty/premium sangat besar.

2. Kelemahan : terjadinya kesenjangan hasil LITBANG ke aplikasi komersial; belum terbentuknya keterkaitan-kemitraan yang adil antar pelaku; produk hilir belum berkembang, 
masih terpaku pada kebutuhan konsumsi lokalan dan yang terakhir adalah tingginya komponen dan struktur biaya produksi pengolahan kopi (tidak terjangkau pelaku bisnis lokal).

3. Peluang : Pasar internasional sangat terbuka; potensi diversifikasi produk olahan kopi masih besar; kebutuhan pengembangan dengan pendekatan cluster kebun kopi dengan cluster industri pengolahan dalam kelembagaan usaha bersama sangat urgen. Peluang distribusi pendapatan dan income generating petani cukup besar.

4. Ancaman : Hambatan-hambatan sistem distribusi kopi domestik; persaingan dengan produk impor tinggi; Adanya persaingan dalam peruntukkan lahan (alih fungsi lahan) cukup signifikan. Kondisi sosial budaya masyarakat sulit terkendalikan.

\section{Kesimpulan}

\section{Kesimpulan Dan Implikasi Kebijakan}

Besaran potensi (luas areal mencapai 9.448 ha dengan kelembagaan Subak Abian 79 bh, kesesuaian agroklimat serta kawasan indikasi geografis beserta citarasa lemon yang khas) maka peluang pengembangan kopi Arabika melalui agroindustri modern merupakan langkah strategis dalam mewujudkan kesejahtraan masyarakat. Hal ini bermakna bahwa orientasi bukan lagi terpaku atas kemurahan alam semata, butuh pengetahuan yang lebih komfrehensif. Meniscayakan rumusan dalam hal optimalisasi pemanfaatan sumber daya alam, SDM, teknologi maju, murah tapi sederhana yang disertai penataan sistem kelembagaan yang kuat. Pembangunan usaha bersama patut diprioritaskan mengingat potensi kawasan dan kemampuan masyarakatnya. Keunggulan komparatif yang meningkat perlu diiringi keunggulan kompetetif melalui penciptaan dayasaing sumberdaya manusia dan masyarakat petani yang profesional guna mendukung terciptanya produk premium untuk kebutuhan pangsa pasar hotel berbintang di Bali.

\section{Implikasi Kebijakan}

Berdasarkan potensi dan kerangka sasaran tersebut upaya-upaya pemerintah dapat diprioritaskan melalui program-program berikut:

1. Penguatan akses ekonomi masyarakat tani terhadap sumber pembiayaan publik.

2. Penguatan kualitas sumberdaya petani termasuk kualitas jajaran aparat birokrasi

3. Pengembangan kualitas prasarana/sarana pendukung langsung kegiatan pembangunan usaha kelompok

4. Pengembangan kelembagaan dalam basis sistem agribisnis sebagai satu entitas bisnis

5. Penguatan dan pengembangan kelembagaan keuangan yang dimiliki dan dikelola oleh masyarakat lokal.

\section{Daftar Pustaka}

Masterplan Pengembangan Kawasan Perkebunan Berbasis Kopi Arabika Provinsi Bali. Dinas Perkebunan Provinsi Bali. 2015

Laporan Kajian Komoditas Kopi Kopyol. Dinas Perkebunan Provinsi Bali. Kerjasama dengan Fakultas Pertanian Universitas Udayana 2012.

Statistik Perkebunan Bali. Pemerintah Provinsi Bali Dinas Perkebunan. 2015

Data Profil Kawasan Industri Masyarakat Perkebunan Bali (KIM-BUN). 2000 
Laporan Tahunan Dinas Perkebunan Provinsi Bali . 2014. 